\title{
Italian viticulture: A multi-faceted model of development and regression
}

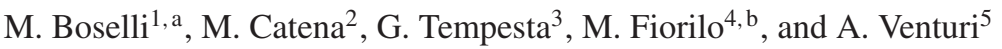 \\ ${ }^{1}$ Università degli Studi di Verona, Department of Biotechnology, Villa Lebrecht, Via della Pieve 70, 37029 San Floriano (VR), Italy \\ ${ }^{2}$ Accademico della Vite e del Vino, via Gentile da Fabriano 25, 61032 Fano (Province of Pesaro Urbino), Italy \\ ${ }^{3}$ Vivaio Enotria, Via Campagnole 2, 31050 Cavasagra di Vedelago (Province of Treviso), Italy \\ ${ }^{4}$ Web editor for "De Vulpe et Uva" \\ ${ }^{5}$ Grapegrower and winemaking free-lance expert, Via Pontarchi 1/a 48018 Faenza (Province of Ravenna), Italy
}

\begin{abstract}
Wine can be considered a niche product on the drinks market, due to the annual turnover it generates and the dispersion of the productive matrix which controls its production. However, it takes on a symbolic value compared to other drinks and boasts a unique link with the territory. Typicity translated into territorial values has brought about the success of winemaking regions of great national and international fame. However, it is necessary to communicate the values and adopt the consequent measures for other areas in a secondary position or with an intermediate development. The value of wine ex-cellar, unbottled and before vat has been analyzed taking into account production in different market segments, a basic element for estimating the value of the GSP per hectare of vineyard. This paper is based on the study of physical, economic and motivational parameters that determine the primary value, the cause for consolidating or abandoning winegrowing. Decisions made by the vinegrower translate into nursery demand which, in turn, determines the varieties and surface areas of the future vineyard.
\end{abstract}

\section{Introduction}

Wine is the oldest drink in the world. It originated in the Caucasus and developed in the territories of the "Fertile Crescent"; it soon conquered the European continent and, centuries later, America and the southern hemisphere, arriving more recently in Asia.

Its peculiarity of being an alcoholic drink strongly conditioned by the natural and anthropic system in which it developed, has been enriched by symbolic and hedonistic values that have influenced its development and consequently its economic importance.

This paper focuses on the value that winegrowing has taken on in Italy, where strong territorial and entrepreneurial differences remain. These are the reasons for success as well as the cause of a possible regression in many of the areas involved.

\subsection{The development of the italian system}

Vinegrowing in Italy has ancient origins and this has favoured and conditioned typicity by linking its fate to the various territories and their historic traditions.

Its development was strongly influenced by the launch of the European agricultural policy and the specific CMO wines that followed later [1].

Another conditioning element of the winegrowing system has been cooperation [2]. It has brought together a very fragmented social basis per territory (today represented by less than $50 \%$ of the 310,428 farms

\footnotetext{
a e-mail: maurizio.boselli@univr.it

b e-mail: www.devulpeetuva.com
}

with vineyards) and has transferred added value from processing and marketing to the vinegrowers.

This cooperation lies within an extended supply chain, which contrasts with the system of valorising grapes of the private winegrowing estates (integrated supply chain) and industrial wineries. The latter thrive on the limits of the supply chain, which are accentuated over time by changes induced by EU winegrowing policies, which can be summarised in four distinct stages:

- 1960s, 1970s development of productivity;

- 1980s reduction of supply;

- 1990s control of supply;

- 2000s shift towards markets and sustainability.

This evolution has conditioned the efficiency of our supply chains on a regional level, accentuating territorial differences. A positive element occurred with the launch of the appellation policy (law 164/92), which has generated a third supply chain over time, that of the districts, where companies pursue a common aim represented by the valorisation of territorial DO and IG wines, under the guiding and valorising action of the Consortia.

To date, the top positions of the wine quality pyramid have increased significantly (our processing of AGEA, ISTAT and FEDERDOC data referring to wine production in 2017):

- DOCG wines 6\%;

- DOC wines 23\%;

- IGT (Indicazione Geografica Tipica) wines 18\%;

- General wines indicating the variety $1 \%$;

- General wines $52 \%$.

(C) The Authors, published by EDP Sciences. This is an Open Access article distributed under the terms of the Creative Commons Attribution License 4.0 (http://creativecommons.org/licenses/by/4.0/). 


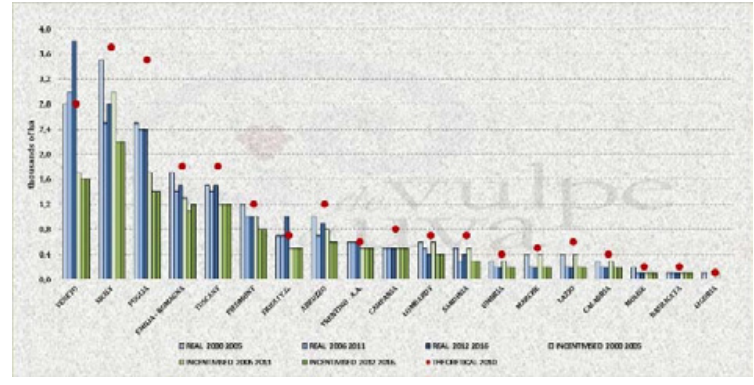

Figure 1. Vineyard renewal in Italy on a regional level.

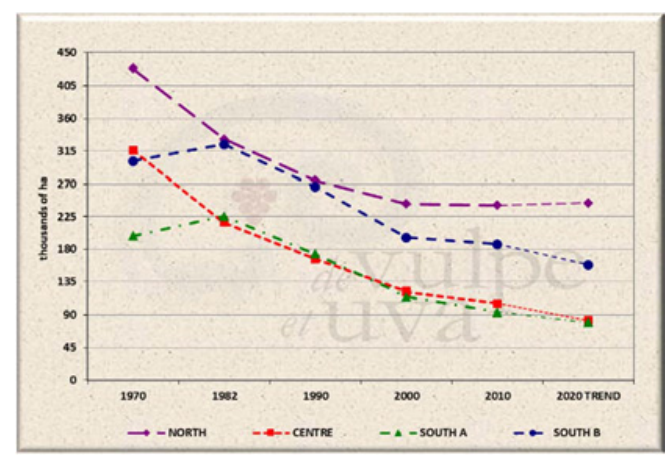

Figure 2. Evolution of vineyard surface areas in Italy.

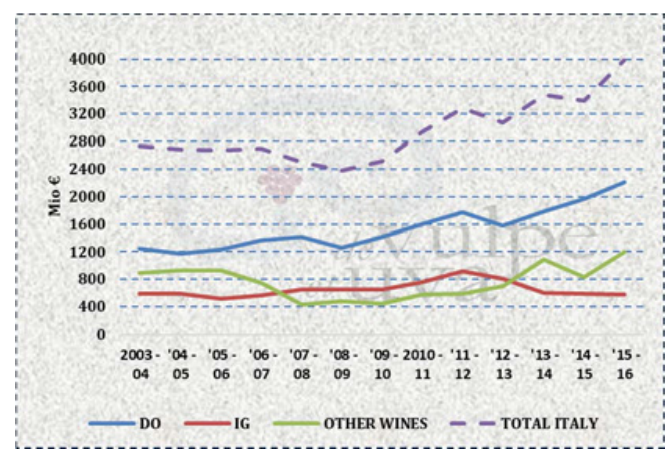

Figure 3. The value of wines ex-cellar, unbottled and before vat per category.

Table 1. The value of wines ex-cellar, unbottled and before VAT, per category (Mio $€$ ).

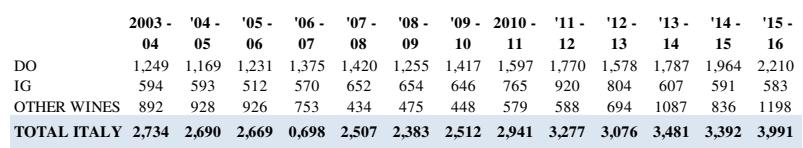

However, different causes have favoured an uneven development in the territories, creating supply chains with different efficiencies [3].

The current scene has witnessed a consolidation of winegrowing in some areas in recent years, while in others it is declining, as illustrated in Fig. 1.

Vineyard renewal with a recovery quota estimated at $3.3 \%$ as a physiological value, shows a lack of uniformity due to the success of some regional viticulture. The positive difference of Veneto and Friuli Venezia Giulia can be largely explained by the success of Prosecco.

Three regions stand out with renewal values that are nearer to the physiological data: Emilia Romagna, Tuscany and Piedmont.

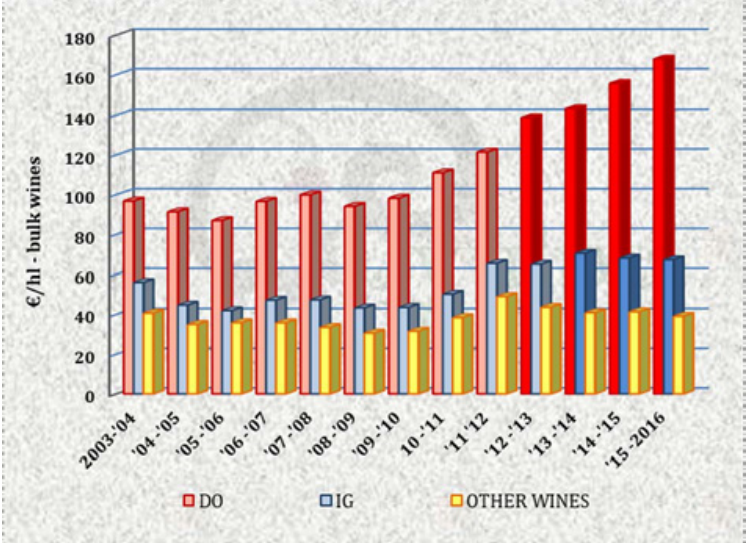

Figure 4. Territory values and wine market segmentation in Italy.

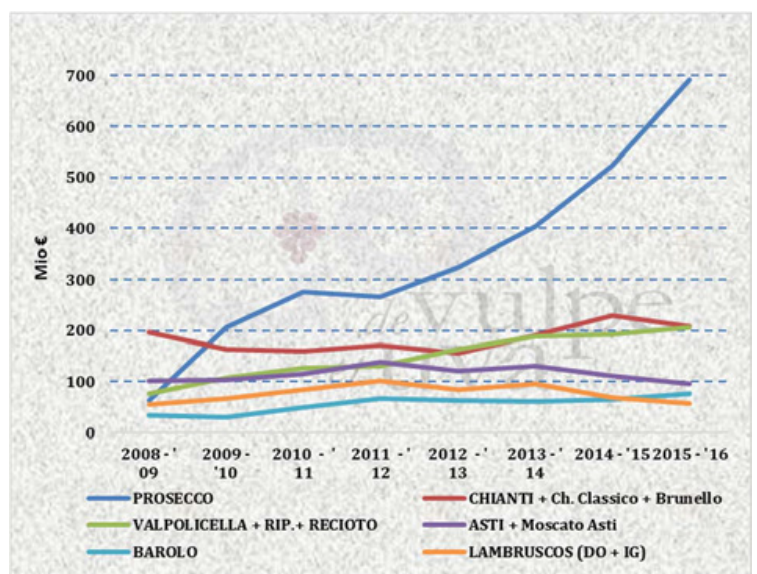

Figure 5. The value of the main DO wines ex-cellar, unbottled and before VAT (Mio $€$ ).

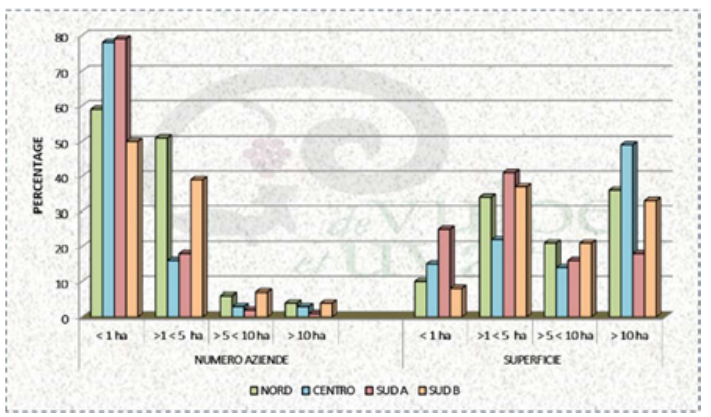

Figure 6. A comparison between the number of wineries and the vineyard surface area per macro area.

Regions with higher surface areas (Sicily and Puglia) are further from the ideal threshold, below which there is a decline in viticulture. The discriminant lies in differences in the profitability of viticulture.

This also explains the different evolution of vineyard surface areas per macro area, which only shows a positive trend for those in the north of the country (Fig. 2).

\section{Territory values}

The value of wines ex-cellar, unbottled and before VAT, and therefore the profitability of vinegrowing, stems from the success of DO wines, due to the evolution of 


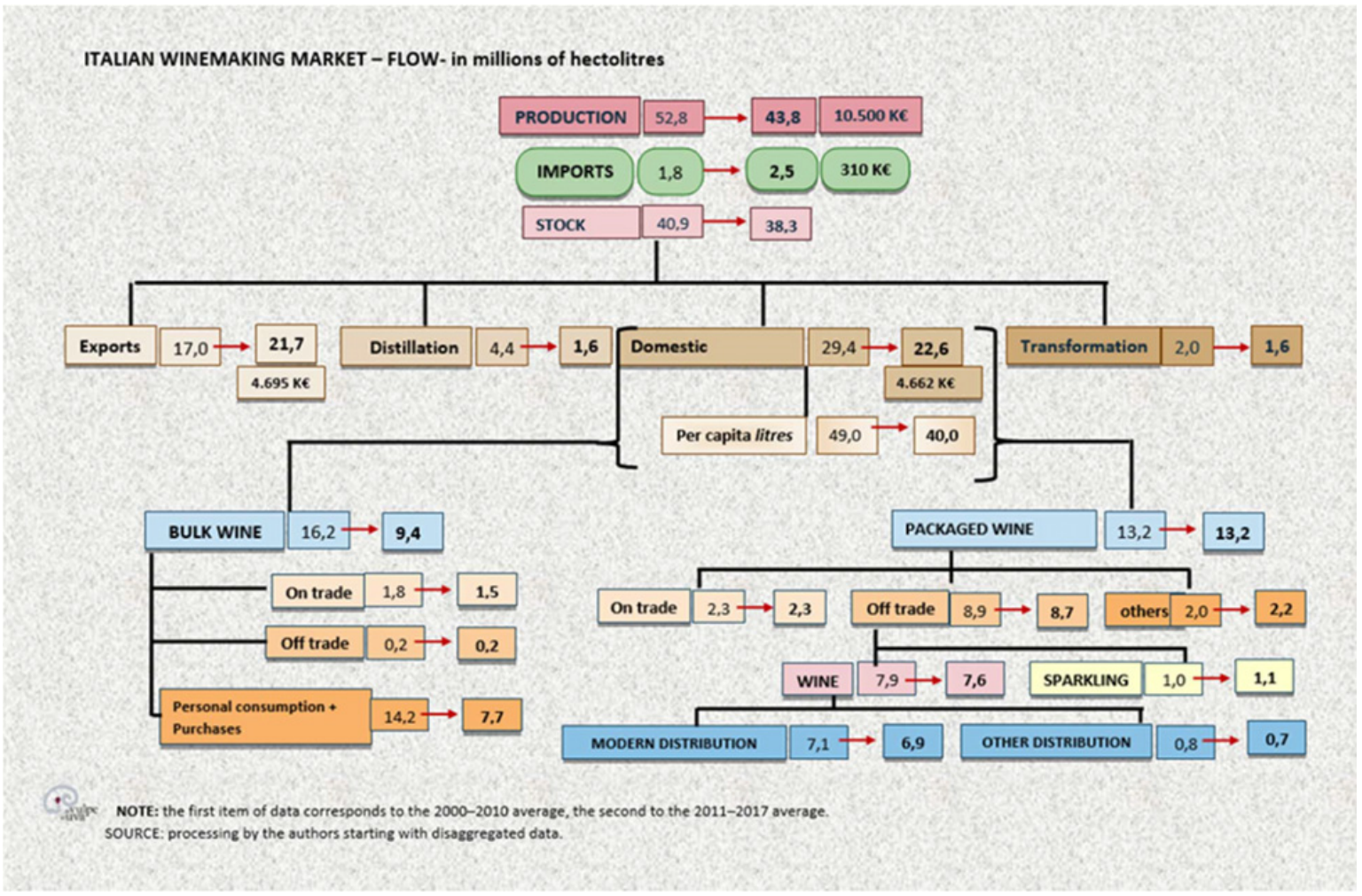

Figure 7. Italian winemaking market - Flow in millions of hl.

Table 2. The value of the main DO wines ex-cellar, unbottled and before VAT (Mio $€$ ) in Italy.

\begin{tabular}{lccccccccc} 
& \multicolumn{10}{c}{ Mio $€$} \\
& $\mathbf{2 0 0 8}$ & $\mathbf{2 0 0 9}$ & $\mathbf{2 0 1 0}$ & $\mathbf{2 0 1 1}$ & $\mathbf{2 0 1 2}$ & $\mathbf{2 0 1 3}$ & $\mathbf{2 0 1 4}$ & $\mathbf{2 0 1 5}-$ \\
& $\mathbf{0 9}$ & $\mathbf{1 0}$ & $\mathbf{1 1}$ & $\mathbf{1 2}$ & $\mathbf{1 3}$ & $\mathbf{1 4}$ & $\mathbf{1 5}$ & $\mathbf{1 6}$ \\
PROSECCO & 62 & 205 & 277 & 267 & 324 & 404 & 523 & 691 \\
CHIANTI + Ch. Classico + Brunello & 196 & 165 & 160 & 171 & 157 & 192 & 230 & 208 \\
VALPOLICELLA + RIP.+ RECIOTO & 77 & 107 & 127 & 131 & 165 & 188 & 192 & 206 \\
ASTI + Moscato Asti & 101 & 103 & 115 & 138 & 121 & 132 & 112 & 96 \\
BAROLO & 34 & 30 & 50 & 66 & 62 & 62 & 65 & 77 \\
LAMBRUSCOS (DO + IG) & 55 & 67 & 85 & 102 & 85 & 96 & 68 & 58 \\
SIGNIFICANT DO WINES & $\mathbf{5 2 5}$ & $\mathbf{6 7 7}$ & $\mathbf{8 1 4}$ & $\mathbf{8 7 4}$ & $\mathbf{9 1 4}$ & $\mathbf{1 , 0 7 2}$ & $\mathbf{1 , 1 9 0}$ & $\mathbf{1 , 3 3 5}$ \\
\% & $\mathbf{2 2 . 1}$ & $\mathbf{2 6 . 9}$ & $\mathbf{2 7 . 7}$ & $\mathbf{2 6 . 6}$ & $\mathbf{2 9 . 7}$ & $\mathbf{3 0 . 7}$ & $\mathbf{3 5 . 1}$ & $\mathbf{3 3 . 5}$ \\
TOTAL ITALY & $\mathbf{2 , 3 8 0}$ & $\mathbf{2 , 5 1 4}$ & $\mathbf{2 , 9 4 2}$ & $\mathbf{3 , 2 8 2}$ & $\mathbf{3 , 0 7 7}$ & $\mathbf{3 , 4 9 2}$ & $\mathbf{3 , 3 9 3}$ & $\mathbf{3 , 9 8 6}$
\end{tabular}

life styles, consumption patterns and increased consumer awareness [4].

This translates into an increase in packaged wines, which are subject to a higher added value and profile compared to IG wines and bulk wine (Table 1, Figs. 3 and 4).

Figure 4 illustrates the above, highlighting how the average value of DO wines in 2016 was $1.68 € / 1$ compared to $0.67 € / 1$ for IG wines and $0.39 € / 1$ for general wines.

Table 2 and Fig. 5 analyse some Designations of Origin, confirming the Prosecco phenomenon and the consolidation on markets of designation wines produced in the centre and north of the country.

\section{Vinegrowing wineries}

According to the 2010 census, the average (see distribution per class of surface area, Fig. 6), was 1.7 hectares of vineyards per winery, while ISMEA (Institute of Services for the Agricultural Food Market, Rome, Italy) data for 2017 [5] talks of 2.08 ha, with a loss of just over 70,000 wineries. This shows that many areas are destined to abandonment due to generational change and low profitability.

\section{The wine market}

Figure 7 summarises the main wine flows, comparing the latest averages (2011-2017) with the previous period (2000-2010). It shows how the supply chain feeds a market where, faced with a drop in production, there has been a significant increase in exports, a drop in bulk wine sales and a strong segmentation of the distribution system. These phenomena are positive overall, but they are not able to reward the winegrowing system in a balanced way.

This situation is clearly linked to the strengths or weaknesses of the system in the different territories (critical mass, the fame of wines in Italy and abroad and the ability to interact with the national and international distribution system).

In 2017 we recorded wine production equal to 45.6 Mio hl, 35.4\% of which certified DOC or DOCG, which generated an industrial turnover of just over 13 billion $€$, equal to $9.8 \%$ of that of Italy's agri-food industry.

This situation is influenced by the different GSP/ha calculated on a territorial level and shown in diagram form in the maps (Figs. 8 to 11), which illustrate how many of the districts in the north exceed the vital threshold of $5000 € /$ ha.

In the central district, with the exception of Tuscany, values fall below $5000 € /$ ha. This is also the case in southern Italian regions, where there are some marginal wineries with incomes decidedly below $5000 € /$ ha.

The statistical error, derived from several marginal vineyards observed mainly in central or southern Italy, is clear. 


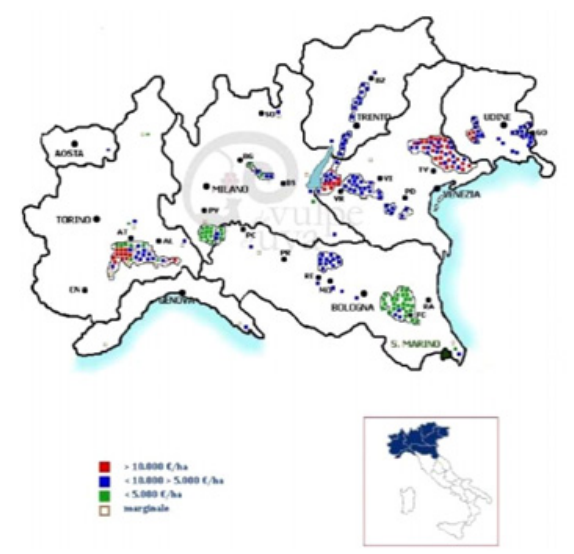

Figure 8. Italian wine districts GSP/ha - north.

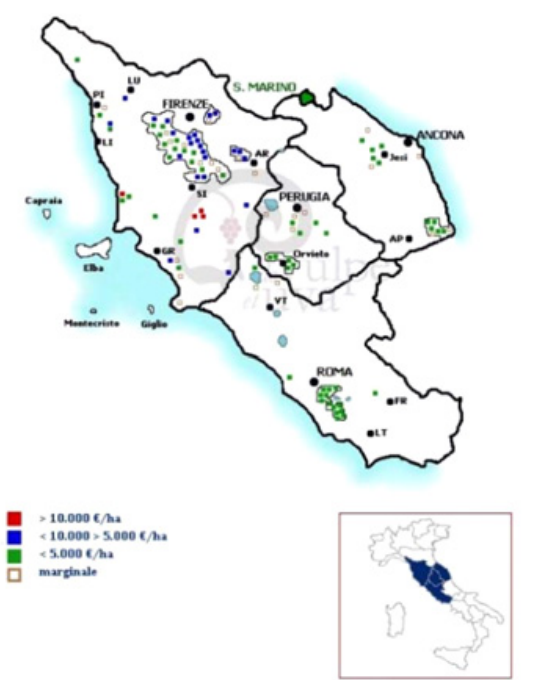

Figure 9. Italian wine districts GSP/ha - centre.

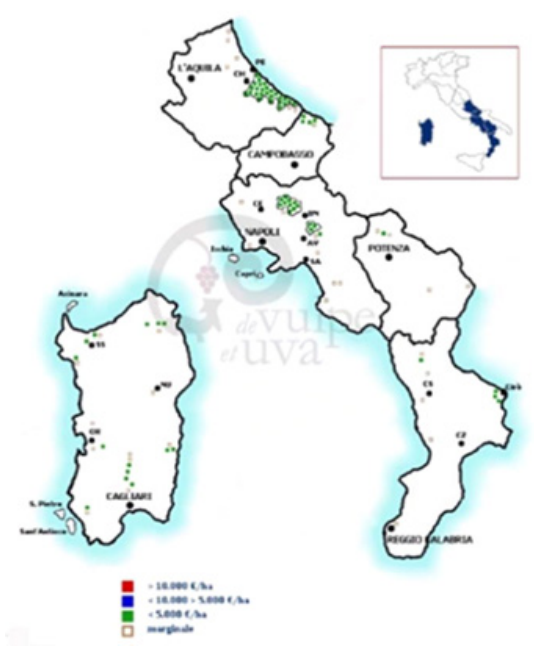

Figure 10. Italian wine districts GSP/ha - south A.

\section{Wine production}

As for wine production, ISMEA records 45,733 wineries making wine in Italy in 2015, however 34,166 of these handle volumes between 0 and $100 \mathrm{hl}$. On the other hand, the Observatory created by the 4 main cooperatives indicates that just 498 cooperatives guarantee $92 \%$ of the total turnover.

Table 3 only takes into account the most significant wineries and divides Winemakers (total and cooperatives)

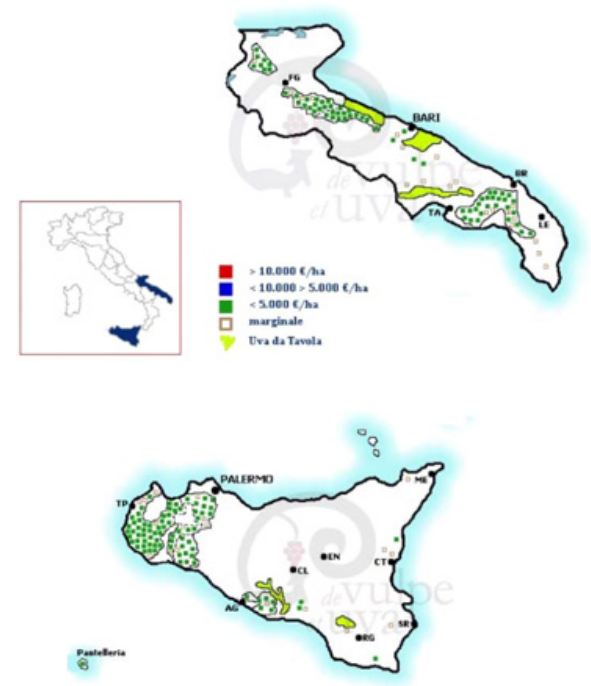

Figure 11. Italian wine districts GSP/ha - south B.

Table 3. Winemaking industry in Italy.

\begin{tabular}{|c|c|c|c|c|c|c|c|c|}
\hline & \multicolumn{8}{|c|}{ ITALY } \\
\hline & \multicolumn{4}{|c|}{ number of wine producers } & \multicolumn{4}{|c|}{ thousands of hl wine } \\
\hline & 2006 & 2009 & 2011 & 2015 & 2006 & 2009 & 2011 & 2015 \\
\hline$<100 *$ & 59,084 & 51,500 & 51,145 & 34,166 & 860 & 590 & 550 & 536 \\
\hline $101-1.000$ & 10,414 & 8,413 & 8,380 & 8,023 & 3,200 & 2,750 & 2,800 & 2,827 \\
\hline $1.001-10.000$ & 2,992 & 2,394 & 2,375 & 2,853 & 7,500 & 5,950 & 6,500 & 7,652 \\
\hline $10.001-50.000$ & 589 & 441 & 440 & 468 & 12,400 & 9,570 & 9,500 & 9,894 \\
\hline$>\mathbf{5 0 . 0 0 0}$ & 230 & 252 & 185 & 223 & 23,157 & 24,564 & 21,282 & 27,833 \\
\hline TOTALS & 14,225 & 11,500 & 11,380 & 11,567 & 46,257 & 42,834 & 40,082 & 48,206 \\
\hline ITALY & 73,309 & 63,000 & 62,525 & 45,733 & 47,117 & 43,424 & 40,632 & 48,742 \\
\hline \multicolumn{9}{|c|}{$\begin{array}{l}\text { NOTE: * wine producers producing less than } 100 \mathrm{hl} \text { operate for self-consumption or informal } \\
\text { markets. }{ }^{*} \text { Cooperatives below } 1,000 \mathrm{hl} \text { are closing or not operating. }\end{array}$} \\
\hline \multicolumn{9}{|c|}{ COOPERATIVE WINERIES } \\
\hline & \multicolumn{2}{|c|}{ No. Wineries } & \multicolumn{2}{|c|}{ thousands of hl } & & & & \\
\hline$<100 *$ & 46 & & 0 & & & & & \\
\hline $101-1.000$ & 94 & & 30 & & & & & \\
\hline $1.001-10.000$ & 139 & & 570 & & & & & \\
\hline $10.001-50.000$ & 187 & & 4,660 & & & & & \\
\hline$>50.000$ & 159 & & 19,540 & & & & & \\
\hline TOTALS & 485 & & 24,770 & & & & & \\
\hline ITALY & 625 & 743 & 24,800 & 24,500 & & & & \\
\hline
\end{tabular}

by Production Class to represent the evolution of the Italian system.

The presence of wineries below $100 \mathrm{hl}$ of production is significant. They are a remnant of a manorial economy strongly linked to the territory ( $1 \%$ of wine produced). Also significant is the plethora of 8023 wineries between 100 and $1000 \mathrm{hl}(5.6 \%$ of production) that can only live by supplementing their income in tourist areas such as Tuscany, Piedmont, Trentino Alto Adige and Veneto.

Our analysis considered the wineries with the following classification:

- Wineries structured in networks (44): with vineyards and cellars in the main Italian winegrowing areas.

- Bottling and wine-producing wineries (66): linked to and often replacing cooperatives.

- Winegrowing wineries (168) with over a million bottles or significant turnovers.

- Wineries with fewer than a million bottles.

The table shows the sample under observation concerning $90 \%$ of bottled wine and $84 \%$ of the turnover (13 billion euros). 
Table 4. Summary of wineries and groups structured in networks with production over a million bottles.
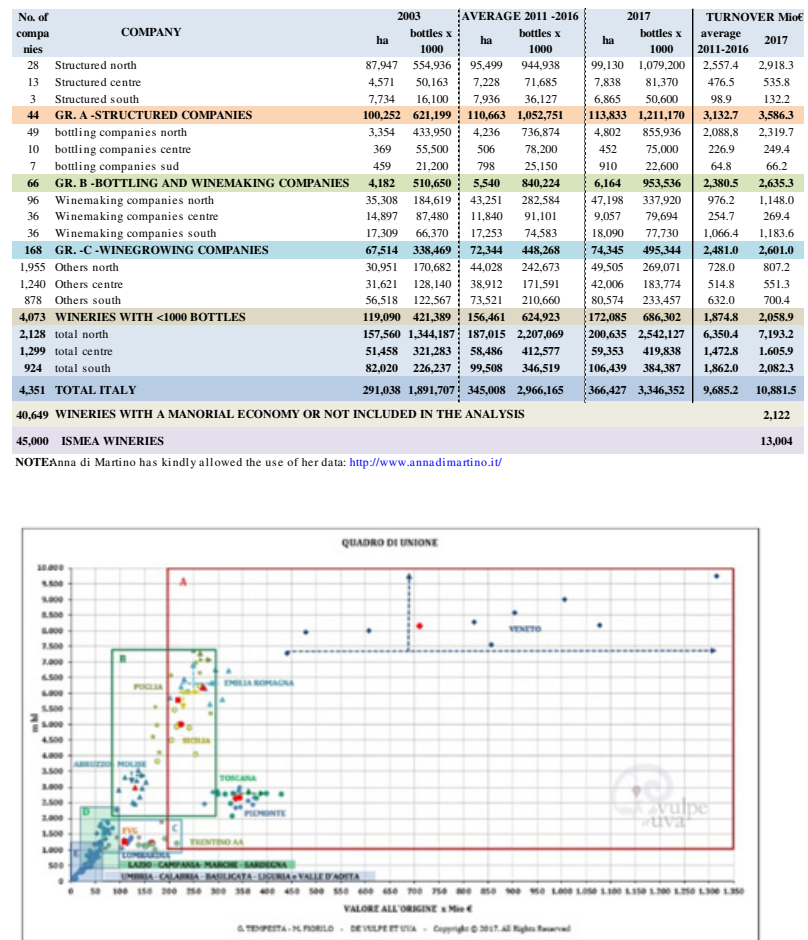

Figure 12. Volumes and economic value of wines ex-cellar, unbottled and before VAT in the different Italian regions.

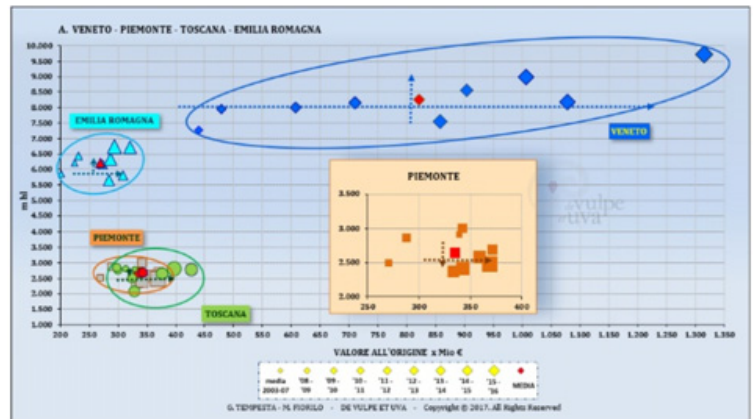

Figures 12a. Volumes and economic value of wines ex-cellar, unbottled and before VAT for the Veneto, Piedmont, Tuscany and Emilia Romagna.

\section{Economic performance on a regional level}

The following figures explain how some areas (regions), such as the Triveneto, have seized the opportunity and latched onto markets; others, such as Tuscany and Piedmont, aim for quality production or stand out for their productive efficiency and organisation, like EmiliaRomagna.

Most of central and southern Italy, headed by Sicily and Puglia, aims at commodities.

The overview is illustrated in Fig. 12, while Fig. 12a compares the best-performing wineries dedicated to exports (Figs. 13 and 14) and highlights the extraordinary development of the Veneto over the years.

Figure 12c compares smaller wineries per volume, but they are comparable to those in Fig. 12a in terms of performance.

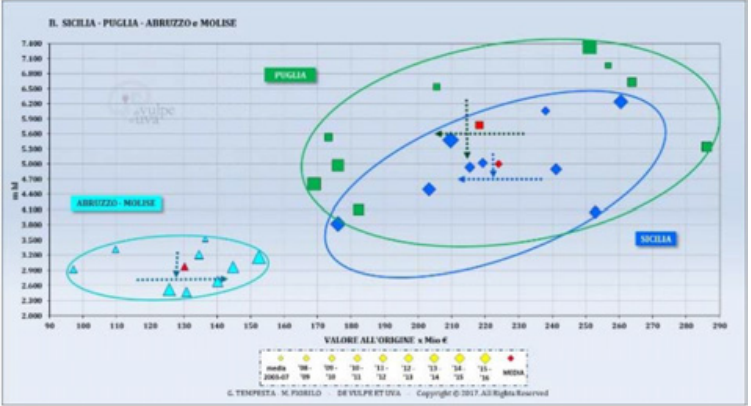

Figures 12b. Volumes and economic value of wines ex-cellar, unbottled and before VAT for Sicily, Puglia, Abruzzo and Molise.

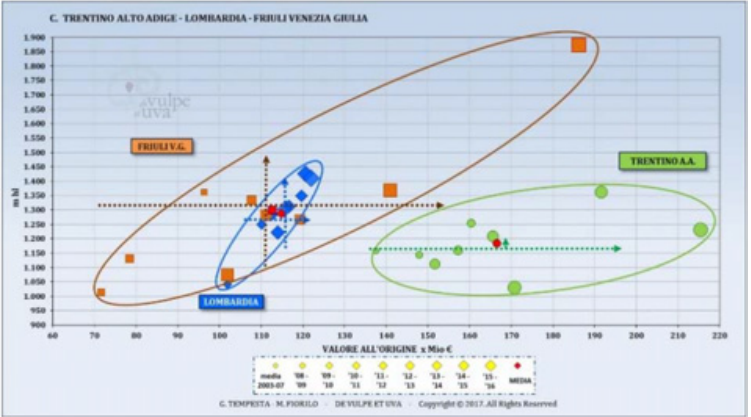

Figures 12c. Volumes and economic value of wines ex-cellar, unbottled and before VAT for Trentino Alto Adige, Lombardy, Friuli V.G.

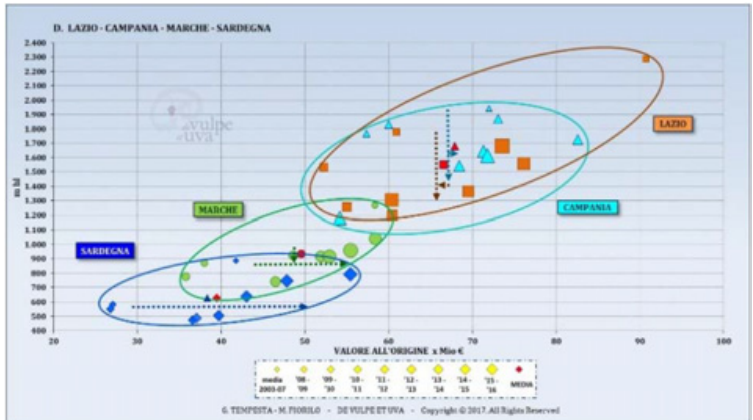

Figures 12d. Volumes and economic value of wines ex-cellar, unbottled and before VAT for Lazio, Campania, Marche and Sardinia.

The significant gap between these two groups and those contained in Fig. 12b is clearly shown by the comparison between high volumes and turnovers that highlight the low unitary valorisation. This is linked to the fourth group (Figs. 12d and 12e) with unrewarding performances due to different situations: crisis for little known wines, business shortcomings, uneven development of the territory.

The more or less accentuated diffusion of volumes and values from 2003 to 2016, with the average (red diamond) at the centre of the vectors.

In addition to differences ascribable to a higher capacity for global turnover and a tendency to exports, it must be underlined how some regions owe their success to the efficiency of wineries operating in their territories. The two phenomena are obviously the result of a synergic stimulus.

This is confirmed by Mediobanca's [6] yearly analysis on the national winegrowing system which assesses the financial reports of 155 of the main Italian limited 


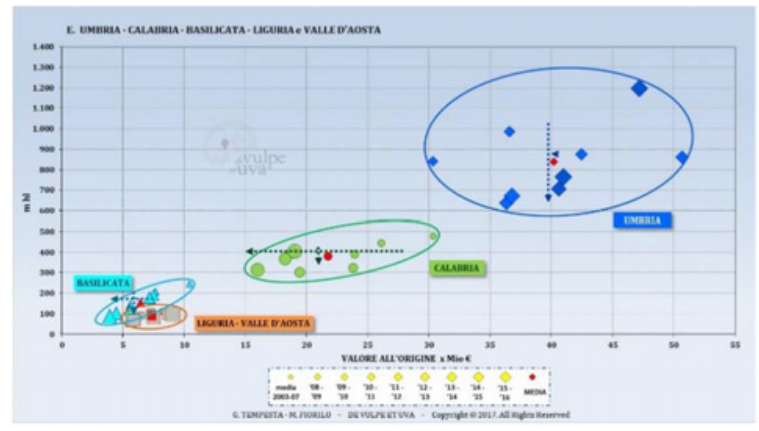

Figures 12e. Volumes and economic value of wines ex-cellar, unbottled and before VAT for Umbria, Calabria, Basilicata, Liguria and Valle d'Aosta.

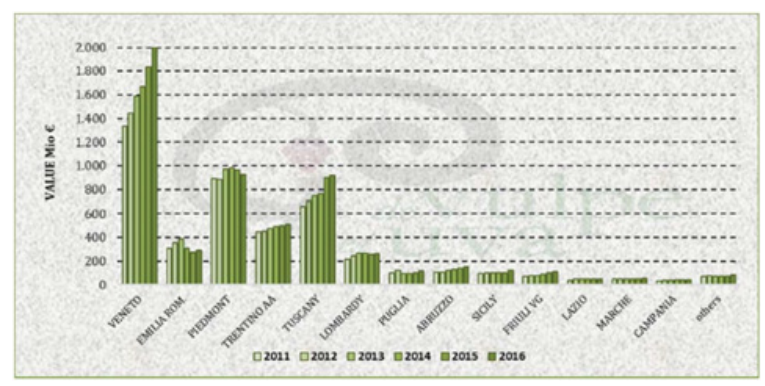

Figures 13. Wine exports per region in value.

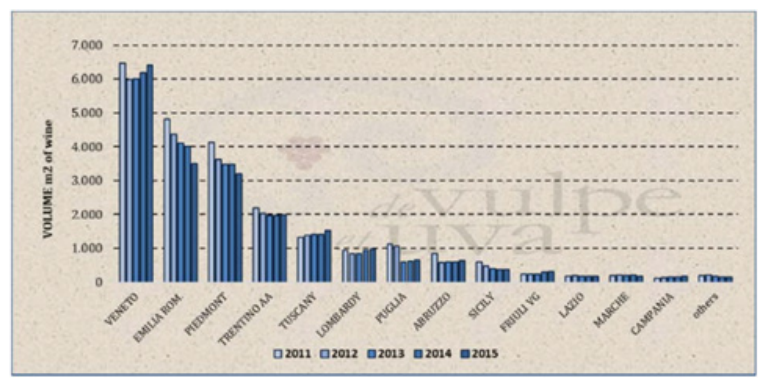

Figures 14. Wine exports per region in volume.

Table 5. Performance indicators on a regional basis (2015).

\begin{tabular}{|l|r|r|r|r|}
\hline Regione & $\begin{array}{r}\text { Margine Op. Netto / } \\
\text { Valore aggiunto }\end{array}$ & $\begin{array}{r}\text { Valore aggiunto / } \\
\text { Capitale Investito }\end{array}$ & Roi & Export in \% \\
\hline Veneto & 37.3 & 23.7 & 9.2 & 59.2 \\
\hline Emilia Romagna & 16,3 & 17.4 & 3.5 & 36.3 \\
\hline Piemonte & 32,8 & 21.0 & 7.1 & 61.5 \\
\hline Toscana & 45.7 & 18.0 & 8.7 & 65.3 \\
\hline Trentino A. A. & 30.6 & 18.5 & 5.8 & 65.1 \\
\hline
\end{tabular}

companies (49 cooperatives, 94 joint stock and limited liability companies, 12 foreign controlled) working in the sector who invoiced over 25 million euros.

A comparison of these values on a regional level (Table 4) confirms the north-south divide: in 2015 the companies belonging to the regions indicated in Table 5 exceed the others when it comes to profitability (ROI: Return on Investment) and vocation for exports.

Wineries in Veneto and Tuscany also show more capital strength and higher efficiency (lower effect of labour costs per product unit).

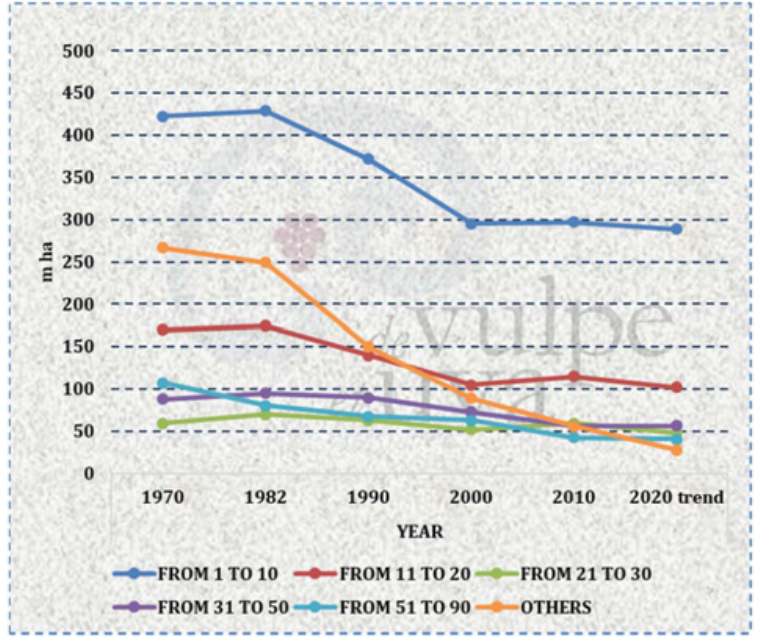

Figures 15. Varietal evolution hectares per decile.
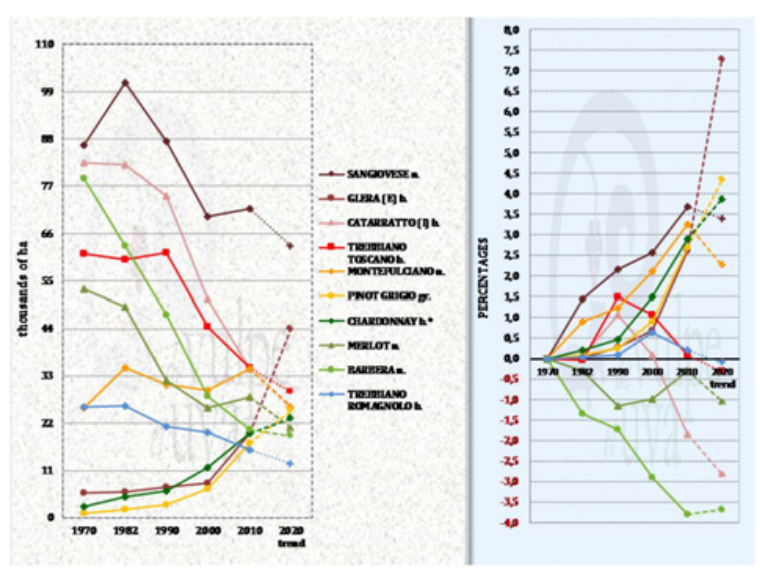

Figures 16. Italian vineyard, evolution of the top ten varieties.

\section{Varietal evolution}

As we have said above, vineyard surface area has decreased and we are likely to see a further drastic reduction: from $1,113,000$ ha in 1970 to 626,400 ha in 2010 , with a forecast of 565,000 ha for 2020 .

At the same time there has been a gradual focus on major grape varieties and a sheer drop in minor ones, with a slightly growing trend for the other varieties (Figs. 15 and 16).

Of the top ten varieties, six (Sangiovese, Trebbiano toscano, Trebbiano romagnolo, Catarratto, Barbera and Montepulciano) are traditional varieties, which have been recently joined by a further four (Glera, Merlot, Chardonnay and Pinot Grigio), illustrating market trends.

The two Trebbianos, Merlot and Barbera are on the decline, with a decrease also expected for Sangiovese and Montepulciano [4].

However, the minor varieties are sustained by the vast number of cases of Designation wines (DO and IGT), through which national or native varieties are valorised. They follow the fate of the designations and the consequent regional fragmentation.

This has pinpointed groups of varieties that characterise the various regions, in addition to those already mentioned. 


\section{Conclusion}

As we have shown, Italy maintains its well-deserved role as leader in the world winegrowing sector, due to the suitability of its territory, its production system able to create wealth, also thanks to the fame of its wines on an international level.

However, this hasn't come about in a uniform way, gradually rewarding viticulture more geared towards the market and with better production organisation.

This situation has created a rift between some regions in central-southern Italy and those in central-northern Italy. This is aggravated by the fact that the former, who assumed a subordinate attitude in the past compared to the economy of the latter, may compromise their future development.

The consequence is a different response to the positive evolution of latest EU policy, with the risk that the gap isn't bridged, but actually widens.

An uneven growth of territorial wineries is one of the main reasons behind fears of a regression of our winegrowing system; a risk stressed by the diffusion and difficulty in using official data on which to base the planning of the sector.

This makes decision-making by the key players in the chain (vinegrowers and their immediate representatives: the nurserymen) more uncertain.

We have briefly highlighted the main weaknesses of our system:

1. Risk of explanting and transferring vineyards between central-southern and northern Italy (hence the regulatory obstacles that have recently been issued: amendment to Ministerial Decree $15^{\text {th }}$ December 2015 no. 12272, of 13/2/2018) which undermines the traditional basis of our viticulture.

2. Abnormal spread of a few leading varieties with serious consequences for the territory's endurance in the face of a market crisis.

3. Crises in the nursery industry which could compromise the fate of a sector suffering from a lack of cohesion and internal planning.

4. Erosion of the nation's set of grape varieties, one of the richest in the world with 504 varieties registered and a potentially higher number of unregistered varieties (at least another 300).

5. The integration of the supply chain has facilitated the development of large family-run wineries and cooperatives, as well as district supply chains geared towards precise wine types.

This has guaranteed an increase in quality and an improvement in economic performance.

However, we need to mention the development of bottling companies, at the top of the system today for turnover, which are not tied to the supply chain and not always linked to quality wines.

These businesses have made marketing and market aggressiveness their creed, regardless of the fate of the supply territory.

6. Family-run wineries (integrated supply chain) see their development conditioned by high financial costs connected to higher capital equipping (vineyards).

Cooperatives reduce their possibility to invest capital in processing structures and marketing, owing to lower profitability linked to mutuality - transferring wealth to the vinegrower - often to the detriment of the winery's financial statement.

This imposes an industrial concentration in order to increase the efficiency of the main structures to the detriment however of marginal wineries, with a transfer of wealth from the more disadvantaged primary areas where there is a higher presence of inefficient wineries.

7. The individualistic view and suitability to gigantism of some businesses, slows down the network development of smaller businesses in terms of a diversification of their portfolio also with nonterritorial products.

8. A system that is not integrated into the global context and often linked to products with foreign company brands or controlled by these.

In brief, a balanced development of the country needs to be stimulated, supported by precise information about the productive structure and diversified regional winegrowing policies.

Otherwise there is the real risk that one of the world's historic winemaking nations will step down from its traditions in order to follow new countries (with a recent or more long-standing development) on the road to globalization, where quality is an intrinsic concept to the product and variety, and less linked to a vocation to viticulture, the great source of our past successes.

The authors thank Jane Upchurch for the English translation.

\section{References}

[1] E. Pomarici, R. Sardone, L'OCM Vino. La difficile transizione verso una strategia di comparto, INEA (2011)

[2] AAVV., Osservatorio della cooperazione agricola italiana, La Cooperazione vitivinicola associata, 107 (2016)

[3] G. Malorgio, E. Pomarici, R. Sardone, A. Scardera, D. Tosco, La catena del valore nella filiera vitivinicola, Agriregionieuropa 27, 147 (2011)

[4] TOLOMEO Università Degli Studi Di Trieste Dipartimento Di Scienze Politiche E Sociali, Le filiere agroalimentari tra innovazione e tradizione, Rapporto finale della ricerca (2013)

[5] T. Sarnari, Vino: scheda di settore, ISMEA (2018)

[6] G. Barbaresco, Il vino italiano e lo scenario globale, (Area Studi Mediobanca, Unione Industriali Asti, 2018)

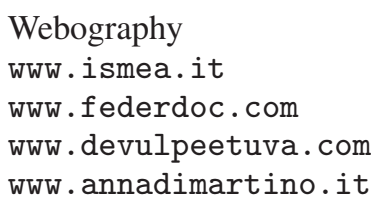

For further information and a more complete database, visit: www . devulpeetuva.com 